Article

\title{
Effect of Bed Material on Bed Agglomeration for Palm Empty Fruit Bunch (EFB) Gasification in a Bubbling Fluidised Bed System
}

\author{
Tanakorn Kittivech and Suneerat Fukuda * \\ The Joint Graduate School of Energy and Environment, Center of Excellence on Energy Technology and \\ Environment, King Mongkut's University of Technology Thonburi, Bangkok 10140, Thailand; \\ tanakorn.k@intusoftech.com \\ * Correspondence: suneerat@jgsee.kmutt.ac.th; Tel.: +662-470-8309
}

Received: 1 October 2019; Accepted: 8 November 2019; Published: 14 November 2019

\begin{abstract}
The high level of potassium compounds in Empty Fruit Bunch (EFB) induces ash-related problems, such as bed agglomeration, which is caused by the formation of a low-melting-point sticky compound: $\mathrm{K}_{2} \mathrm{On} \cdot \mathrm{SiO}_{2}$, especially in fluidised bed gasification using silica sand as bed material. Dolomite was found to be an effective alternative bed material for preventing bed agglomeration by the release of $\mathrm{CaO}$ via calcination processes during gasification. $\mathrm{CaO}$ acts as a catalyst to inhibit bed agglomeration by possibly enhancing the formation of $\mathrm{K}_{2} \mathrm{CO}_{3}$ instead of $\mathrm{K}_{2} \mathrm{O} \cdot \mathrm{nSiO}_{2}$. Alumina sand was also found to be a suitable alternative bed material to prevent bed agglomeration; however, due to the relatively high density of alumina sand, high gas velocity was needed to ensure good mixing and fluidisation. Using both dolomite and alumina sand as bed materials yielded a product gas having similar higher heating value (HHV) to that when using silica sand (i.e., 3.8-3.9 $\mathrm{MJ} / \mathrm{Nm}^{3}$ ).
\end{abstract}

Keywords: bed agglomeration; fluidised bed; dolomite; alumina sand; gasification; EFB; biomass

\section{Introduction}

Fluidised bed is a promising technology in energy production and has many advantages over other types of technologies [1]. Due to good heat distribution, combustion efficiency is enhanced. In a fluidised bed reactor, inert, small, solid particles-e.g., silica sand-are used as a heat transfer and heat storage medium, which is called "bed material". The principle of fluidised bed is moving the bed materials by force of the gas flowing through the bed material at a suitable velocity range [2].

Gasification involves a thermochemical process which converts solid fuel to combustible gas containing $\mathrm{CO}, \mathrm{H}_{2}$, and hydrocarbon gases as the combustible fraction. This gas is called "producer gases" [3]. In fluidised bed gasification, bed agglomeration is a major barrier when using fuels that contain high levels of alkali minerals-e.g., sodium ( $\mathrm{Na}$ ) and potassium (K) [4]. The alkali minerals possibly react with silicon $(\mathrm{Si})$ in the surrounding and form a sticky compound with a low melting point. This sticky compound later causes bed agglomeration [5].

In Thailand, agricultural waste has huge potential, since a large proportion of it is still unused [6] -including palm empty fruit bunches (EFBs). EFBs are the residue generated in the palm oil milling process, and the remaining potential is around $2.5 \mathrm{Mt} /$ year [7]. Using EFB as fuel in combustion boilers to supply energy to palm oil mills has been attempted. Due to the high alkali content in EFB, ash-related problems, including fouling depositions in superheater tubes and bed agglomeration in fluidised bed, are expected to cause more frequent shutdowns.

So far, only a few studies have considered the gasification of EFB in fluidised bed systems. Lahijani and Zainal studied the effects of bed temperature and equivalence ratio (ER) on the producer gas 
quality of EFB gasification in bubbling fluidised bed using silica sand as bed material [8]. The results showed that $\mathrm{EFB}$ gasification $\left(\mathrm{ER}=0.25\right.$ ) at very high temperature, i.e., $1050{ }^{\circ} \mathrm{C}$, yielded the producer gas having satisfactory higher heating value (HHV) at $5.88 \mathrm{MJ} / \mathrm{Nm}^{3}$. However, at bed temperature higher than $\mathrm{T}=790^{\circ} \mathrm{C}$, bed agglomeration was the major issue for EFB gasification. Lahijani et al. later conducted a similar investigation on the effects of bed temperature on gasification performance using dolomite as the bed material [9]. They revealed that, at the same bed temperature, using dolomite as the bed material could result in higher producer gas HHV than using silica sand. However, when the bed temperature was high, i.e., $>850^{\circ} \mathrm{C}$, bed agglomeration could also visually be observed for dolomite bed but the level of agglomeration when using dolomite was less severe compared to that when using sand. Chaivatamaset et al. studied factors that affect bed agglomeration tendencies and the bed agglomeration mechanism in a fluidised bed reactor using EFB as fuel but under combustion conditions [10]. The study revealed that factors such as air velocity and bed particle size could affect the bed agglomeration tendencies. In that study, the bed agglomeration was found to occur at a lower bed temperature, i.e., as low as $750{ }^{\circ} \mathrm{C}$, compared to studies of EFB gasification discussed above. Those studies [8-10] then suggested the range of temperatures in which ash-related problems, or, more specifically, bed agglomeration, are likely to occur during EFB gasification in bubbling fluidised bed operations.

A previous study of EFB gasification and occurrence of de-fluidisation when using silica sand as bed material by the authors revealed that, under the conditions studied, the optimal air-to-fuel ratio or ER that gives the best HHV was 0.35 [11]. However, bed agglomeration was found in every ER in the range of 0.31 to 0.43 , where the bed temperature was always higher than $750{ }^{\circ} \mathrm{C}$. Using lower ERs for gasification to achieve bed temperatures lower than $750{ }^{\circ} \mathrm{C}$ may prevent bed agglomeration, but poor gasification efficiency due to low bed temperature is not favourable [12].

There were suggestions for alternative bed materials such as alumina sand to be used instead of silica sand to reduce bed agglomeration in a fluidised bed [13]. Recently, Ninduangdee and Kuprianov studied the effect of using dolomite and alumina sand as bed materials for palm kernel shell (PKS) combustion in a fluidised bed combustor on bed agglomeration [14]. The results revealed that dolomite and alumina sand could be used as bed material for PKS combustion without bed agglomeration.

Literature has shown that $\mathrm{K}$ content in fuels is another main factor that affects bed agglomeration tendencies in fluidised bed combustion [10]. Moreover, the lower $\mathrm{O}_{2}$ and operable temperature in gasification could result in different bed agglomeration behaviours and de-fluidisation temperatures. Also, in the case of using high alkali biomass like EFB as fuel for gasification, the solution for overcoming bed agglomeration in bubbling fluidised beds has, so far, not been established. The effect of using various bed materials on gasification performance and bed behaviours must be investigated before use in commercial scale. The results from this study could provide useful information for the design and operation of industrial-scale gasification processes using high alkali biomass especially EFB.

The ultimate goal of this study is to investigate bed behaviours and the possibility to prevent bed agglomeration by using alumina sand and dolomite as alternative bed materials to silica sand in fluidised bed gasification of high $\mathrm{K}$ biomass fuel like EFB. The effects of using dolomite and alumina sand on producer gas composition, heating value, gas yield, and gasification efficiency were also investigated to assess the energy potential of using EFB as fuel. Experiments were conducted using a 5-kW air-blown bubbling fluidised bed reactor at the selected ER of 0.35 .

\section{Methodology}

\subsection{Biomass Properties and Preparation}

Fresh EFBs were supplied from the southern part of Thailand, the region where majority of the oil palm industry is located. Due to the extremely high moisture content, EFBs were dried under direct sunlight; then, the size of EFB was reduced from long fibres to approximately $1-4 \mathrm{~mm}$ by an 
agricultural hammer mill machine. To eliminate the effect of moisture content, the samples were dried in an oven at $110^{\circ} \mathrm{C}$ overnight before use. Prepared samples were kept in an airtight container.

Small portions of EFB were powdered and subjected to property analysis. Ultimate and proximate analyses were conducted using an elemental analyzer (Thermo Scientific - Flash EA 1112, USA) and a thermogravimetric analyzer (PerkinElmer - Pyris 1 TGA, USA), respectively. The properties of EFB are given in Table 1.

Table 1. Properties of Empty Fruit Bunch (EFB).

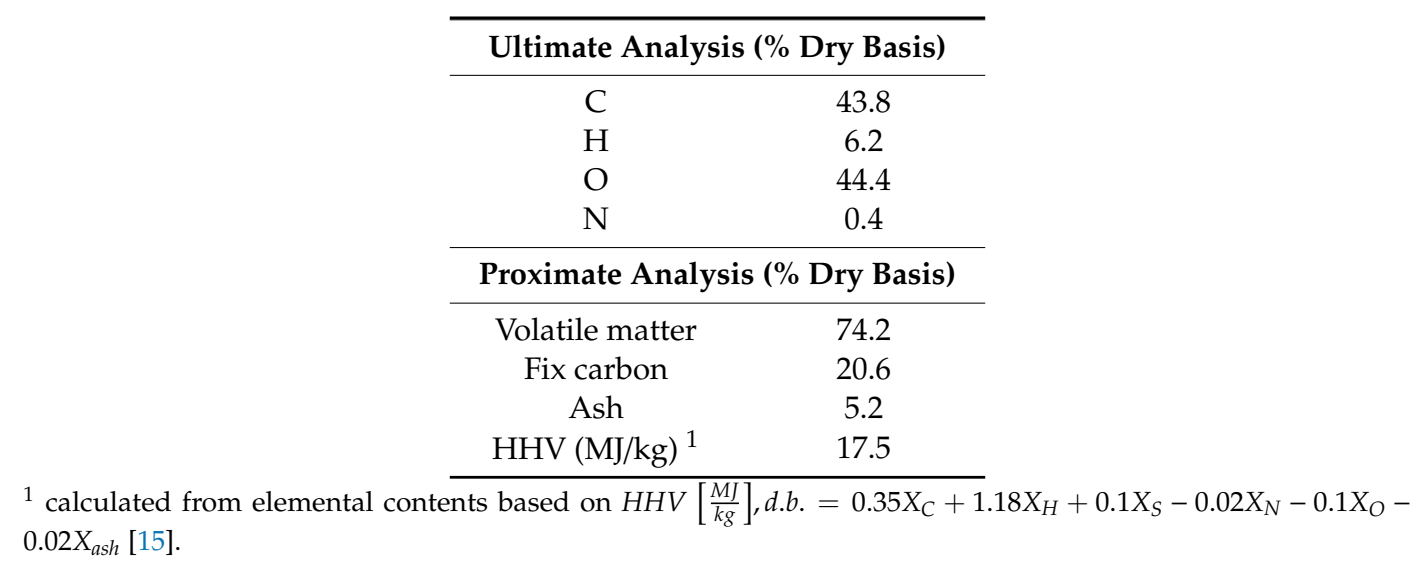

To analyse oxide composition in the EFB ash, a small amount of EFB was burned in a muffle furnace following the American Society for Testing and Materials (ASTM) D-1102 standard at a temperature of $575{ }^{\circ} \mathrm{C}$ overnight. At $575{ }^{\circ} \mathrm{C}$, the carbon in the fuel was removed but most of the minerals remained in the ash. The composition in the EFB ash was analysed using the X-ray fluorescence (XRF) technique (Bruker S8 tiger). The obtained XRF spectrum is shown in Figure 1. It was also calculated and converted into oxide form as shown in Table 2. The major elements found were $\mathrm{K}, \mathrm{Si}$, and $\mathrm{Cl}$.

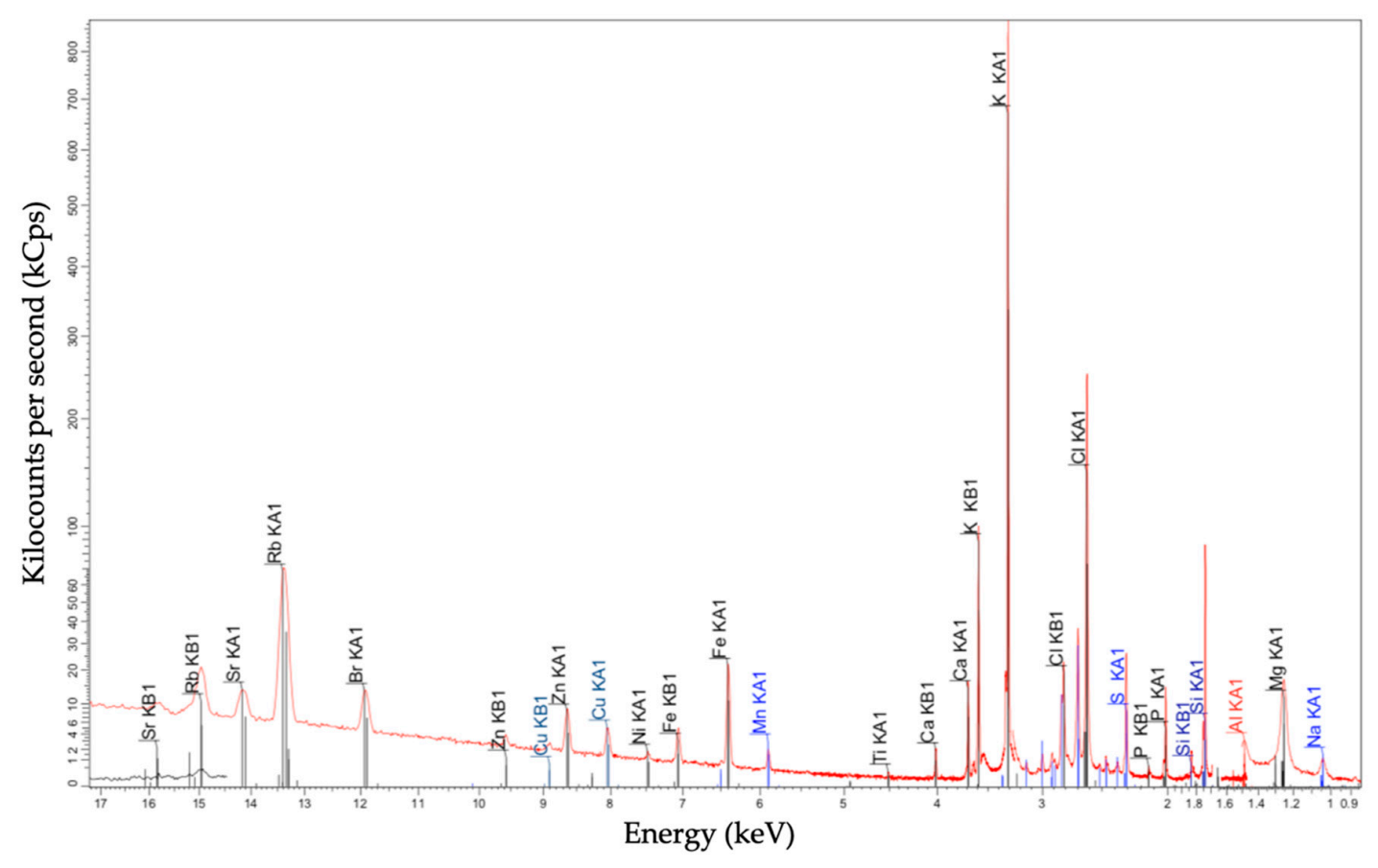

Figure 1. X-ray fluorescence (XRF) spectrum of EFB ash. 
Table 2. Oxide composition of EFB ash by X-ray fluorescence (XRF) analysis.

\begin{tabular}{|c|c|}
\hline \multicolumn{2}{|c|}{$\begin{array}{c}\text { Oxide Composition } \\
\text { (\% By Weight, Dry Ash Basis) }\end{array}$} \\
\hline $\mathrm{SiO}_{2}$ & 14.6 \\
\hline $\mathrm{CaO}$ & 2.2 \\
\hline $\mathrm{MgO}$ & 2.9 \\
\hline $\mathrm{Fe}_{2} \mathrm{O}_{3}$ & 0.5 \\
\hline $\mathrm{K}_{2} \mathrm{O}$ & 61.2 \\
\hline $\mathrm{SO}_{3}$ & 2.0 \\
\hline $\mathrm{Na}_{2} \mathrm{O}$ & 0.5 \\
\hline $\mathrm{P}_{2} \mathrm{O}_{5}$ & 2.0 \\
\hline $\mathrm{Cl}$ & 14.1 \\
\hline
\end{tabular}

\subsection{Bed Materials}

Silica sand is generally used as bed material in commercial fluidised beds due to its large availability. In this study, silica sand was therefore used as a reference bed material. Apart from silica sand, dolomite and alumina sand were selected as alternative bed materials to study the effect of bed material on bed agglomeration mitigation. The bed materials were sieved to an average size of $250 \mu \mathrm{m}$. A small portion of each bed material was analysed for its oxide composition via the XRF technique. The physical properties and oxide composition of bed materials are shown in Table 3.

Table 3. Physical properties and oxide composition of various bed materials.

\begin{tabular}{cccc}
\hline Properties & Silica Sand & Dolomite & Alumina Sand \\
\hline Mean particle size $(\mu \mathrm{m})$ & 250 & 250 & 250 \\
Bulk density $\left(\mathrm{kg} / \mathrm{m}^{3}\right)$ & 1450 & 1434 & 2014 \\
Particle density $\left(\mathrm{kg} / \mathrm{m}^{3}\right)$ & 2650 & 2850 & 3920 \\
Minimum fluidisation velocity at $760{ }^{\circ} \mathrm{C}$ & 0.06 & 0.04 & 0.08 \\
$\left(\mathrm{U}_{\mathrm{mf}} @ 760^{\circ} \mathrm{C}\right)(\mathrm{m} / \mathrm{s})$ & \multicolumn{2}{c}{} \\
\hline \multicolumn{4}{c}{ Oxide Composition (\% By Weight) } \\
\hline $\mathrm{SiO}_{2}$ & 99.3 & 0.8 & 6.5 \\
$\mathrm{Al}_{2} \mathrm{O}_{3}$ & 0.7 & 0.5 & 87.8 \\
$\mathrm{CaO}^{\mathrm{MgO}}$ & - & 27.1 & 0.5 \\
$\mathrm{TiO}_{2}$ & - & 16.5 & 0.3 \\
$\mathrm{CO}_{3}$ & - & - & 4.1 \\
$\mathrm{Trace}^{2}$ & - & 55.0 & - \\
\end{tabular}

\subsection{Bench Scale Fluidised Bed Reactor Gasification System}

In this study, gasification experiments were conducted in a 5-kW autothermal bench-scale air-blown bubbling fluidised bed gasification system. The minimum fluidisation velocity $\left(\mathrm{U}_{\mathrm{mf}}\right)$ of this system is $0.06 \mathrm{~m} / \mathrm{s}$ (using sand as bed material). The schematic diagram of the gasification system is shown in Figure 2. This system consists of five main parts: (1) air supply unit, (2) fuel feeder, (3) reactor, (4) cyclone, and (5) flare.

The feeder system was designed for solid fuel with less than $2 \mathrm{~mm}$ in diameter and $10 \mathrm{~mm}$ in length. The system was a two-stage screw feeder. The primary screw feeder was installed in the primary hopper (large hopper) and was used to control the feed rate of biomass. The biomass transferred from the primary screw feeder dropped onto the secondary screw feeder, which was operated at high speed to immediately feed the biomass into the reactor. To eliminate the problems of discontinuous biomass feeding and a subsequent unsteady bed temperature during gasification operation caused by the difficulty in feeding low density and fibrous biomass, a stirring shaft was installed inside the primary hopper to untangled and evenly distributed the biomass into the primary screw feeder. 
A bed heater was placed at the bed material zone to heat up the reactor. The cyclone and downstream pipeline were also covered by the auxiliary heater (fixed temperature at $350^{\circ} \mathrm{C}$ ) to prevent tar condensation and subsequent fly ash deposition on the condensed tar. Two thermocouples were installed at $125 \mathrm{~mm}$ above the air distributor and at the top of the reactor. Two pressure transducers were also installed below the air distributor and at the top of the reactor to monitor the pressure drop across the bed.

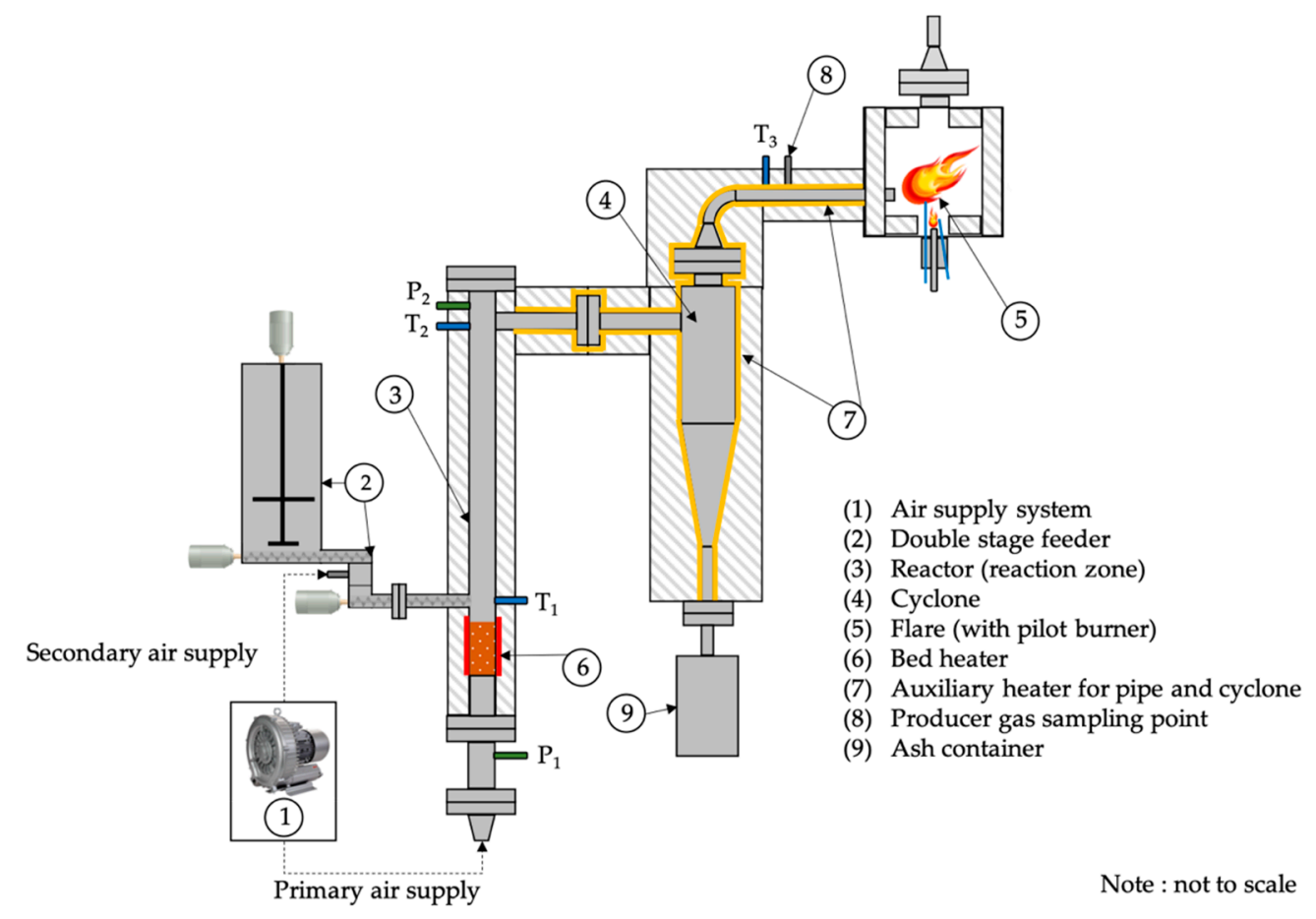

Figure 2. Bench-scale bubbling fluidised bed gasification system.

\subsection{Experiment Procedure}

A series of gasification experiments was designed to examine the effects of bed materials on bed agglomeration mitigation in a fluidised bed. The experiments involved gasification of EFB using three different bed materials (silica sand, dolomite, and alumina sand).

Before each experiment began, $200 \mathrm{~g}$ of fresh bed material was placed into the reactor. For alumina sand, which has a significantly higher bulk density, $250 \mathrm{~g}$ of bed material was used to maintain the same volume of bed material in the reactor. Later, the feedstock was filled in the primary hopper. Then, air was supplied through the primary air inlet (located at the bottom of the reactor) and the secondary air inlet (located at the feeder to assist fuel feeding). The primary air flow rate was fixed at $0.78 \mathrm{~m}^{3} / \mathrm{h}$ to minimise the effect of the gas residence time, whereas the secondary air flow rate was fixed at $0.12 \mathrm{~m}^{3} / \mathrm{h}$. The superficial air velocity $\left(\mathrm{U}_{\mathrm{s}}\right)$ inside the reactor equalled $0.1 \mathrm{~m} / \mathrm{s}$.

To warm up the system, the bed and auxiliary heaters were turned on until the bed temperature reached a steady state at $585^{\circ} \mathrm{C}$. Then, the bed heater was turned off and fuel feeding was started and adjusted to ER 0.35 . The auxiliary heaters continued to heat cyclone and pipeline at $350{ }^{\circ} \mathrm{C}$ throughout the experiment to prevent tar condensation and heat losses. However, some experiments in this study resulted in bed agglomeration and de-fluidisation. In such conditions, the bed temperature would rapidly rise above $950{ }^{\circ} \mathrm{C}$ and could damage the reactor. To avoid that damage, air and fuel supply were stopped to terminate the reactions. 


\subsection{Producer Gas Sampling and Analysis Method}

The gas sampling point was located next to the cyclone. Producer gas was drawn from the main gas line by a vacuum pump at a flow rate of $2 \mathrm{~L} / \mathrm{h}$ after gasification reached a steady-state condition. The sampled gas then passed through a series of two salt-ice cooled impinger bottles; each was filled with isopropanol (IPA) as shown in Figure 3. IPA was used as a solvent to separate unwanted tar from the producer gas. In cases that de-fluidisation was expected, the producer gas would be collected immediately after the bed temperature reached $700{ }^{\circ} \mathrm{C}$.

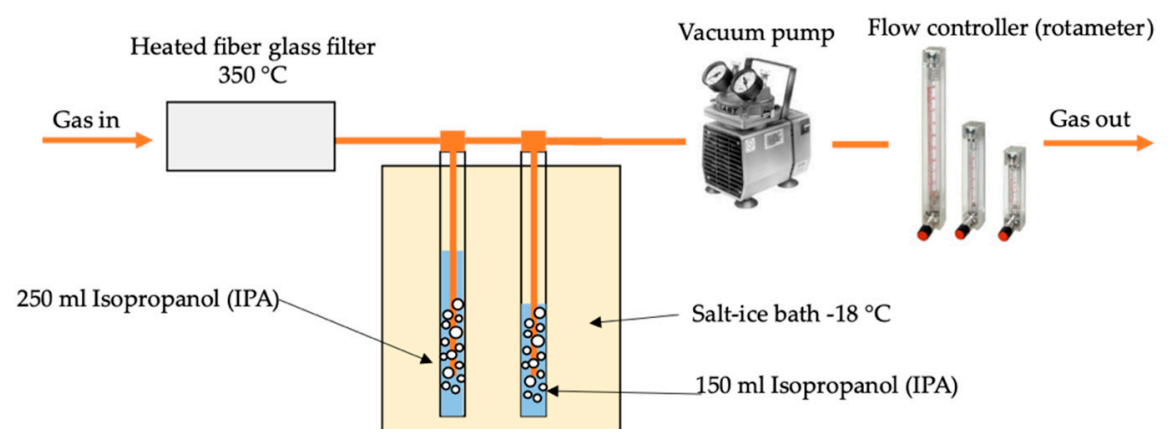

Figure 3. Schematic diagram of the producer gas sampling system.

\subsubsection{Producer Gas Composition Analysis}

Producer gas was collected in 5-liter gas bags and diluted by helium (He) at a ratio of 1:10 before analysis using micro GC (Agilent 490) with MS-5A and Porapak U column installed in parallel. Helium (He) was used as a carrier gas. The temperature of injector was set to $110^{\circ} \mathrm{C}$. The MS-5A column separated $\mathrm{O}_{2}, \mathrm{~N}_{2}, \mathrm{CO}$, and $\mathrm{CH}_{4}$ at a column temperature of $180^{\circ} \mathrm{C}$, whereas the Porapak $\mathrm{U}$ column separated $\mathrm{CO}_{2}, \mathrm{C}_{2} \mathrm{H}_{6}, \mathrm{C}_{2} \mathrm{H}_{2}$, and $\mathrm{C}_{2} \mathrm{H}_{4}$ at a column temperature of $150^{\circ} \mathrm{C}$. The amount of each gas species was detected by a dedicated thermal conductivity detector (TCD) sensor for each column. For hydrocarbon gases larger than $\mathrm{C}_{2} \mathrm{H}_{\mathrm{n}}$, the concentration was measured by GC with flame ionization detector (FID) model Shimadzu GC-2014. The analysis found that the concentration of $\mathrm{C}_{\mathrm{n} \geq 3}$ gases from gasification was less than $0.1 \%$ dry gas basis; thus, the $C_{n \geq 3}$ gases were neglected in this study.

\subsubsection{Higher Heating Value of Producer Gas}

The higher heating value ( $\left.H H V_{d r y ~ g a s}\right)$ of producer gases can be calculated by multiplying the heating value of individual combustible gases in $\mathrm{MJ} / \mathrm{Nm}^{3}\left(\mathrm{Nm}^{3}\right.$ is cubic meter at $\left.25^{\circ} \mathrm{C}, 1 \mathrm{~atm}\right)$ with the volume fraction, including $\mathrm{CO}, \mathrm{CO}_{2}, \mathrm{H}_{2}, \mathrm{CH}_{4}, \mathrm{C}_{2} \mathrm{H}_{2}, \mathrm{C}_{2} \mathrm{H}_{4}$, and $\mathrm{C}_{2} \mathrm{H}_{6}$. The formula for $H H V_{d r y}$ gas can be expressed as follows [16]:

$$
H H V_{d r y ~ g a s}\left(\frac{M J}{N m^{3}}\right)=12.62 Y_{\mathrm{CO}}+12.77 Y_{\mathrm{H}_{2}}+39.78 Y_{\mathrm{CH}_{4}}+58.06 Y_{\mathrm{C}_{2} \mathrm{H}_{2}}+63 Y_{\mathrm{C}_{2} \mathrm{H}_{4}}+69.7 Y_{\mathrm{C}_{2} \mathrm{H}_{6}}
$$

where $Y_{i}$ is the volume fraction of the combustible gas species.

\subsubsection{Dry Gas Yield}

Dry gas yield $\left(\psi_{d g}\right)$ is the ratio of total dry producer gas volume flow rate $\left(\mathrm{Nm}^{3}\right)$ at ambient temperature $\left(25^{\circ} \mathrm{C}, 1 \mathrm{~atm}\right)$ to one kilogram of dry biomass $(\mathrm{kg})$, as shown in the equation below:

$$
\psi_{d g}=\frac{\dot{V}_{d g}}{\dot{m}_{d b}}
$$

where $\dot{m}_{d b}$ is the dry mass flow rate $(\mathrm{kg} / \mathrm{h})$ and $\dot{V}_{d g}$ is the dry gas volume flowrate $\left(\mathrm{Nm}^{3} / \mathrm{h}\right)$ calculated from balancing nitrogen $(\mathrm{N})$ present in producer gas with $\mathrm{N}$ in air and fuel. 


\subsubsection{Carbon Conversion Efficiency}

Carbon conversion efficiency $\left(\eta_{c}\right)$ is the proportion of total carbon present in producer gas to carbon in fuel. Carbon conversion efficiency can be expressed as

$$
\begin{gathered}
\eta_{c}=\frac{\dot{m}_{C, d g}}{\dot{m}_{C, d b}} \times 100 \% \\
\dot{m}_{C, d g}=\dot{V}_{d g} \times\left[\left(\% C H_{4}+\% C O_{2}+\% C O\right)+2\left(\% C_{2} H_{2}+\% C_{2} H_{4}+\% C_{2} H_{6}\right)\right] \times \frac{12}{2240}
\end{gathered}
$$

where $\dot{m}_{C, d g}$ is the mass flow rate of carbon in dry producer gas $(\mathrm{kg} / \mathrm{h})$ and $\dot{m}_{C, d b}$ is the mass flow rate of carbon in dry biomass $(\mathrm{kg} / \mathrm{h})$.

\subsubsection{Cold Gasification Efficiency}

Cold gasification efficiency $\left(\eta_{g}\right)$ is the other indicator for gasification performance and can be described as the potential energy output over the energy input expressed as the following equation:

$$
\eta_{g}=\psi_{d g} \frac{H H V_{d g}}{H H V_{d b}}
$$

where $\psi_{d g}$ is dry gas yield $\left(\mathrm{Nm}^{3} / \mathrm{kg}_{\text {fuel }}\right) ; H H V_{d g}$ is the higher heating value of dry gas $\left(\mathrm{MJ} / \mathrm{Nm}^{3}\right)$; and $H H V_{d b}$ is the higher heating value of dry biomass (MJ/kg).

\subsection{SEM-EDS for Bed Agglomeration Analysis}

Representative samples of spent beds were taken from the bottom of the reactor after the gasification experiments ended and the system had cooled down to room temperature. A small portion of the bed sample was moulded in a $25-\mathrm{mm}$-diameter cylinder block by using clear resin (e.g., Stuers Epo-fix kits). Later, the moulded bed sample was cross-sectioned horizontally with a diamond cutting disc and the cut surface was polished with a diamond polisher before being coated with $99.9 \%$ gold ( $\mathrm{Au}$ ) at a thickness of $20 \mathrm{~nm}$ using gold sputtering coater (Cressington 108-Auto). The finished workpiece was analysed to study changes in the physical structure of the bed samples using a scanning electron microscope (SEM) (Jeol JSM-6610LV) and to measure the elemental composition in the samples using energy dispersive microscopy (EDS) (Oxford INCA-X Art).

\subsection{Error and Uncertainty}

A set of experiments was conducted in a previous study of the authors to determine the systematic error [11]. The experiments were conducted using the same system and under the same condition as in this study but using rubber wood sawdust (RWS) as fuel. The bed temperature was found to vary within $\pm 2 \%$, and the error of producer gas concentration analysis was below $1 \%$.

\section{Results and Discussion}

\subsection{Fluidisation Number and Bed Temperature}

According to the minimum fluidisation velocity $\left(\mathrm{U}_{\mathrm{mf}}\right)$ determined for different bed materials, dolomite requires the lowest $U_{m f}$ due to its low bulk density. Using the superficial velocity $\left(U_{s}\right)$ fixed at $0.1 \mathrm{~m} / \mathrm{s}$, the fluidisation numbers $\left(\mathrm{U}_{\mathrm{s}} / \mathrm{U}_{\mathrm{mf}}\right)$ of dolomite, silica sand, and alumina sand were equal to $2.5 \mathrm{U}_{\mathrm{mf}}, 1.67 \mathrm{U}_{\mathrm{mf}}$, and $1.25 \mathrm{U}_{\mathrm{mf}}$, respectively. A greater fluidisation number indicates a better fluidisation environment (i.e., a higher chance for contact between the fuel and the gasification agent).

From the experiment results, bed agglomeration was observed when using silica sand as the bed material at bed temperatures of around $750{ }^{\circ} \mathrm{C}$. Only the experiment using dolomite as the bed material could still achieve steady-state conditions at a bed temperature of around $750{ }^{\circ} \mathrm{C}$. The experiment using 
alumina sand had to be terminated before the bed temperature reached a steady-state because a fuel blockage problem was observed, likely due to the relatively low fluidisation number of alumina sand.

\subsection{Bed Behaviour}

\subsubsection{Using Silica Sand as Bed Material}

In normal experiments where no agglomeration occurred—as with rubber wood sawdust (RWS) gasification in previous research [11] — the temperature and pressure could be maintained within the operation despite some pressure fluctuation, as shown in Figure 4a.

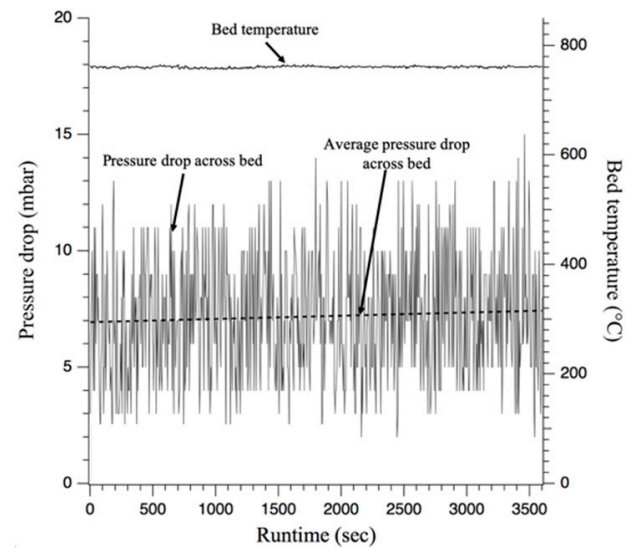

(a)

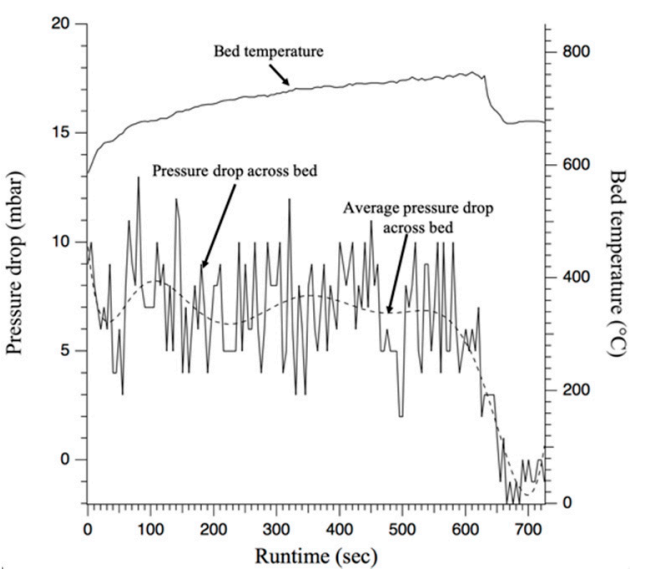

(b)

Figure 4. Pressure and temperature profiles during (a) rubber wood sawdust (RWS) and (b) EFB gasification [11].

Using EFB as fuel, bed agglomeration occurred during gasification and caused de-fluidisation. An example of bed temperature and pressure in the case of EFB gasification using silica sand as bed material is shown in Figure $4 \mathrm{~b}$. The pressure drop across the bed would increase slightly over time-i.e., from 5 mbar to 6 mbar-by the higher pressure built up through agglomerated particles and would be followed by a sudden decrease to almost zero-i.e., at run time $680 \mathrm{~s}$, indicating the de-fluidisation state.

Due to the high amount of $\mathrm{K}$ as indicated by XRF analysis, the low-melting-point $\mathrm{K}_{2} \mathrm{O}$ formed during the early stages of gasification may react with $\mathrm{SiO}_{2}$ in the environment and form a potassium-silicate sticky compound $\left(\mathrm{K}_{2} \mathrm{O} \cdot \mathrm{nSiO}_{2}\right)$, where the $\mathrm{n}$ of $\mathrm{SiO}_{2}$ depends on the concentration of $\mathrm{K}$ in the environment. This sticky compound is the main factor that caused the agglomeration of bed particles.

The agglomerated bed samples from EFB gasification were taken from the bottom of the reactor when the experiment finished. It was found that the bed material (silica sand) colour turned to white-grey because it was coated with a sticky compound. Moreover, most of the bed materials were glued together by this sticky compound-i.e., one group of agglomerated particles contained more than two bed particles. Also, there were large, porous particles (about $4 \mathrm{~cm}$ in diameter) formed by agglomerated particles, which later caused channelling at the bottom of the reactor.

Examples of SEM micrographs of agglomerated bed particle cross sections are shown in Figure 5. The contrast in the pictures reveals the different elements present in the bed samples. The luminous colour (i.e., the lighter colour, light grey, or white) illustrates the area mainly consisting of $\mathrm{K}_{2} \mathrm{O}$ and $\mathrm{SiO}_{2}$. Spots of interest at the circumference of the particles and the connection points between agglomerated particles were analysed via the EDS technique. The spots of interest are labelled as points 1 to 8 in Figure 5. 


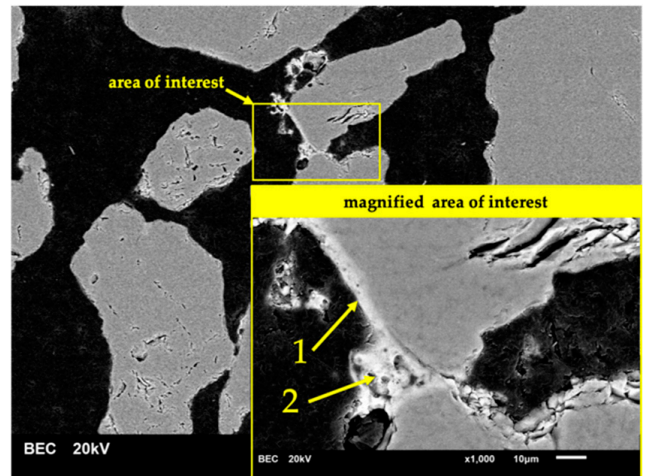

(a)

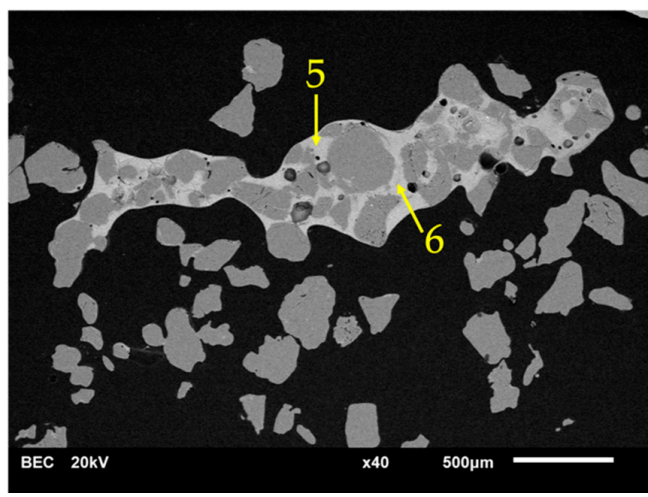

(c)

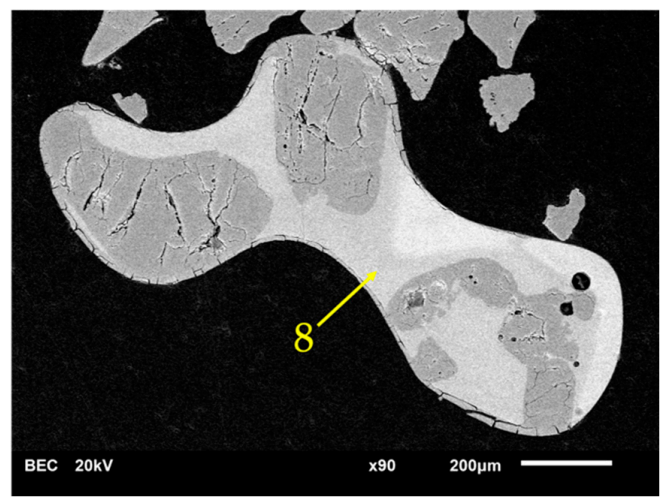

(e)

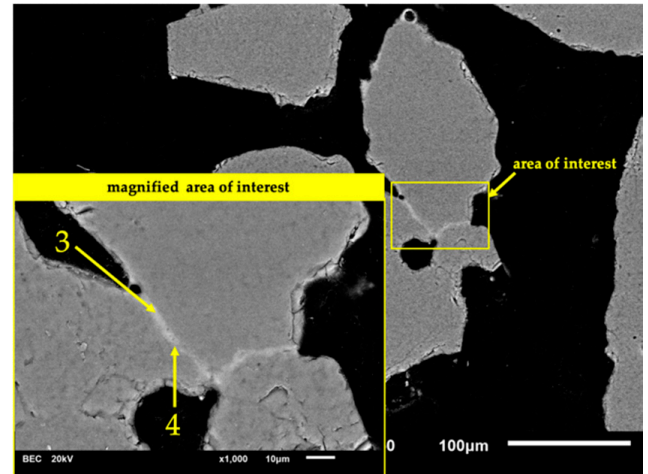

(b)

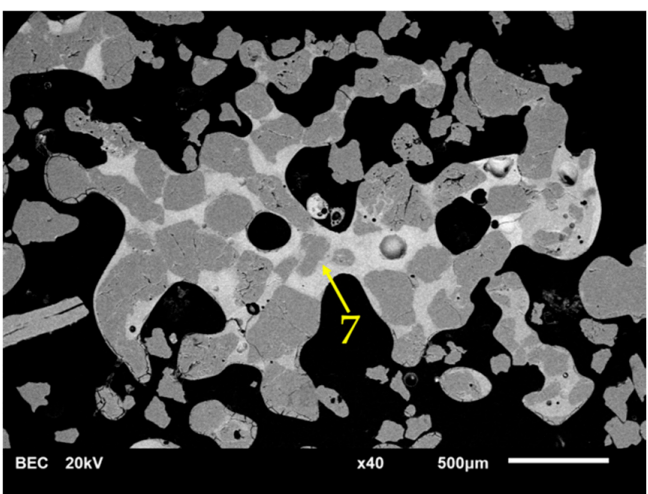

(d)

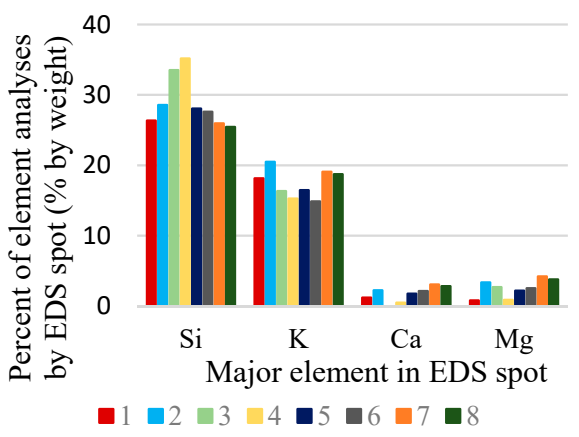

(f)

Figure 5. SEM micrographs (a) and (b) of agglomerated silica sand bed by coating-induced and melt-induced mechanisms, (c) and (d) of large porous agglomerated particles, (e) of intense coating-induced agglomerated particles and (f) EDS spot analysis composition.

According to SEM and EDS spot analysis, most of the agglomerated bed particles found in this study were formed by the coating-induced mechanism as described by Visser et al. [5] -i.e., covered by $\mathrm{K}_{2} \mathrm{O} \cdot \mathrm{nSiO}_{2}$, as presented by the luminous area in Figure 5 (points 1, 3, 4, and 8). The reason is that EFB contains high amounts of $\mathrm{K}_{2} \mathrm{O}$ and $\mathrm{SiO}_{2}$ in their ash. The potassium and silicon compound in the EFB ashes could easily form a potassium-silicate compound $\left(\mathrm{K}_{2} \mathrm{O} \cdot \mathrm{nSiO}_{2}\right)$ at low temperature during gasification. This potassium-silicate compound later coated the bed particles, as presented in Figure 5 .

Apart from the coating induction mechanism, another agglomeration mechanism-the "melt-induced mechanism" was also found in this study. The coated or non-coated beds underwent collision and gluing via the molten phase $\mathrm{K}_{2} \mathrm{O} \cdot \mathrm{nSiO}_{2}$ between the contact points of two bed particles because of the local heat spot created by collision between bed particles [5]. The area connecting the two bed particles is called the "neck". Point 2 in Figure 5a illustrates an example of bed agglomeration via the melt-induced mechanism. 
Due to the high intensity of $\mathrm{K}$ in the system, many small groups of agglomerated bed later developed large porous agglomerated beds via the coating induction and melt-induced mechanisms, as shown in Figure $5 \mathrm{c}, \mathrm{d}$. The large, porous bed later caused channelling inside the reactor, which terminated the fluidisation of the bed.

In summary, the results illustrated that the mechanisms of bed agglomeration involved in this study were coating induced and melt induced. These mechanisms were similar to those found in other research studies in combustion environment $[4,10,17,18]$. The difference between combustion and gasification is the operating condition, i.e., air-to-fuel ratio and bed temperature. In gasification, the lower air-to-fuel ratio (below 0.4) was used to create a reducing atmosphere. The bed agglomeration mechanism was expected to be different from combustion. However, from the results, in the case of using high-alkali biomass, $\mathrm{K}$ and $\mathrm{S}$ were the major factors that play a more dominant role in causing bed agglomeration rather than the atmosphere to which biomass was exposed. The summary of bed agglomeration mechanisms is shown in Figure 6.

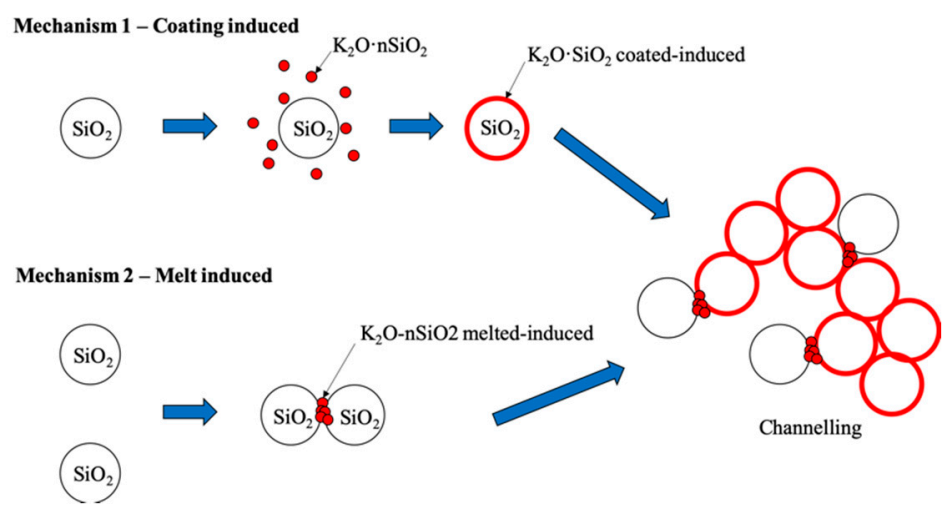

Figure 6. Schematic diagram of agglomeration mechanisms adapted from Reference [5].

Using the element composition information from SEM-EDS analysis in Figure $5 \mathrm{f}$, the element composition of the points 1 to 8 mainly consisted of $\mathrm{K}$ and $\mathrm{Si}$. The results were also plotted as red circles on the $\mathrm{K}_{2} \mathrm{O}-\mathrm{SiO}_{2}-\mathrm{CaO}$ ternary phase diagram in Figure 7 to predict the melting temperature of the sticky compound $\mathrm{K}_{2} \mathrm{O} \cdot \mathrm{nSiO}_{2}$.

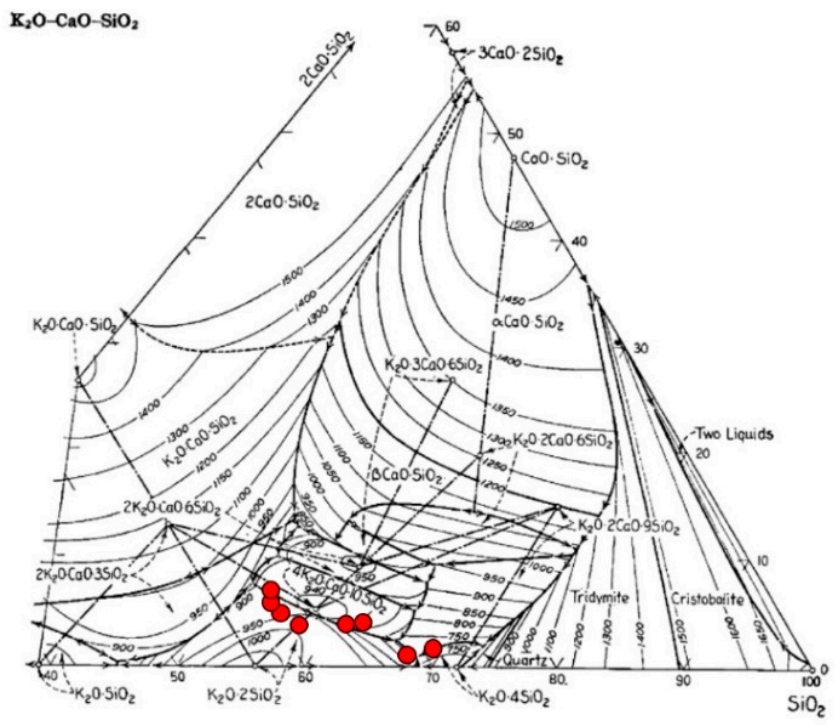

Figure 7. Element composition from spot EDS agglomerated bed particles plotted on the ternary phase diagram of the $\mathrm{K}_{2} \mathrm{O}-\mathrm{CaO}-\mathrm{SiO}_{2}$ system adapted from Reference [19]. 
According to the ternary phase diagram in Figure $7, \mathrm{~K}_{2} \mathrm{O} \cdot 4 \mathrm{SiO}_{2}$ was found to be the compound with the lowest melting point in this study: $750{ }^{\circ} \mathrm{C}$. Moreover, $\mathrm{K}_{2} \mathrm{O} \cdot 4 \mathrm{SiO}_{2}$ was also reported as the major compound in other agglomerated particles in fluidised bed combustion $[4,10,17]$. Compared to the EDS results of EFB combustion in a fluidised bed [10], $\mathrm{K}_{2} \mathrm{O} \cdot 4 \mathrm{SiO}_{2}$ is only the key compound causing bed agglomeration in combustion cases. In gasification, as in this experiment, the compound with a higher ratio of $\mathrm{K}_{2} \mathrm{O}$ to $\mathrm{SiO}_{2}$ (e.g., $\mathrm{K}_{2} \mathrm{O} \cdot 2 \mathrm{SiO}_{2}$ and $4 \mathrm{~K}_{2} \mathrm{O} \cdot \mathrm{CaO} \cdot 10 \mathrm{SiO}_{2}$ ) than $\mathrm{K}_{2} \mathrm{O} \cdot 4 \mathrm{SiO}_{2}$ was also formed.

\subsubsection{Using Dolomite as Bed Material}

Using dolomite as bed material instead of silica sand achieved a significant reduction in bed agglomeration. No bed agglomeration was found throughout the experiment, even at $\mathrm{T}=750{ }^{\circ} \mathrm{C}$. The spent bed, which consisted of dolomite mixed with bottom ash, was analysed by the SEM technique. No coating layer was found on the dolomite particles. The sample of the spent bed was also analysed by the XRF technique. The results of the XRF analysis are shown in Table 4.

Table 4. Oxide composition of dolomite bed before and after use.

\begin{tabular}{ccc}
\hline \multirow{2}{*}{ Oxide Composition } & \multicolumn{2}{c}{ \% By Weight } \\
\cline { 2 - 3 } & Before Use & After Use $^{\mathbf{1}}$ \\
\hline $\mathrm{SiO}_{2}$ & 0.8 & 0.7 \\
$\mathrm{Al}_{2} \mathrm{O}_{3}$ & 0.5 & 0.2 \\
$\mathrm{CaO}$ & 27.1 & 35.8 \\
$\mathrm{MgO}$ & 16.5 & 25.5 \\
$\mathrm{CO}_{3}$ & 55.0 & 35.3 \\
$\mathrm{~K}_{2} \mathrm{O}$ & - & 1.9 \\
Trace & 0.1 & 0.6 \\
\hline
\end{tabular}

${ }^{1}$ spent bed, which consisted of dolomite and bottom ashes.

Dolomite is a compound of calcium and magnesium carbonate $\left(\mathrm{CaMg}\left(\mathrm{CO}_{3}\right)_{2}\right)$. The decomposition of dolomite (e.g., calcination process) produces $\mathrm{CaO}, \mathrm{MgO}$, and $\mathrm{CO}_{2}$ when the temperature reaches $600{ }^{\circ} \mathrm{C}$ and follows Equations (1) and (2).

$$
\begin{aligned}
\mathrm{CaCO}_{3} & \rightarrow \mathrm{CaO}+\mathrm{CO}_{2} \\
\mathrm{MgCO}_{3} & \rightarrow \mathrm{MgO}+\mathrm{CO}_{2}
\end{aligned}
$$

According to the XRF results in Table 4, the remaining oxide compositions $\left(\mathrm{CaO}, \mathrm{MgO}\right.$, and $\left.\mathrm{CO}_{3}\right)$ suggested that the calcination reaction occurred along with the gasification reaction and that it is possible that $\mathrm{CaO}$ and $\mathrm{MgO}$ from the calcination reaction inhibited the formation of $\mathrm{K}_{2} \mathrm{O} \cdot \mathrm{nSiO}_{2}$ at the operational temperature range in this study, i.e., $500-800{ }^{\circ} \mathrm{C}$. The role of $\mathrm{CaO}$ as an inhibitor for bed agglomeration has been reported in other research studies [20,21]. At the same time, the $\mathrm{K}_{2} \mathrm{O}$ in the system possibly reacted with $\mathrm{CO}_{2}$ and formed $\mathrm{K}_{2} \mathrm{CO}_{3}$, which has a high melting point (i.e., $891{ }^{\circ} \mathrm{C}$ ), instead of $\mathrm{K}_{2} \mathrm{O} \cdot \mathrm{nSiO}_{2}$.

From visual observations, the dolomite particle size was reduced to powder size after use. Even though dolomite can minimise bed agglomeration, segregation and bed loss seem to be major issues. There was a decrease in pressure drop across the bed during gasification because the dolomite particle size was becoming smaller by segregation. The decomposition and calcination reactions of dolomite were also thought to play key roles in size reduction. Some sufficiently small bed particles would have escaped with the ascending gas. Bed loss, size reduction, and bed segregation would result in a tremendous decrease in the minimum fluidisation velocity $\left(\mathrm{U}_{\mathrm{mf}}\right)$, which subsequently resulted in a very high fluidisation number. Too high a fluidisation number could result in slug flow (i.e., a phenomenon whereby the bed material is not fluidised because small bubbles of the gasification agent form a large bubble under the bed material). When slug flow occurred, there was less mixing between the biomass and bed material. The gas flow would be blocked and a rapid rise in temperature could occur. It is 
therefore necessary that the pressure drop across the bed is continuously monitored to ensure a stable bed inventory.

\subsubsection{Using Alumina Sand as Bed Material}

Alumina sand required the greatest minimum fluidisation velocity $\left(\mathrm{U}_{\mathrm{mf}}\right)$ among the three bed materials studied because it has a high bulk density. Under the same parameter control as experiments using other bed materials, alumina sand has a very low fluidisation number, which reduces the mixing and shearing rate of biomass. EFB could easily block the gas flow, especially inside the bed zone, resulting in a very short operable run time. The experiment was also conducted at higher air flow, with an ER of 0.55, but the fluidisation number was still too low and the problem of fuel blockage still occurred.

The sample of alumina sand after use from the experiment using ER $=0.35$ was analysed by the SEM technique. According to the SEM results, there was no luminous white-grey colour presented around bed particles like silica sand bed after use, suggesting that there was no $\mathrm{K}_{2} \mathrm{O} \cdot \mathrm{nSiO}_{2}$ compound coating in this after-use bed material.

\subsection{Producer Gas Yield and Gasification Efficiency}

\subsubsection{Effect of Bed Material on Producer Gas Composition and Higher Heating Value}

The product of gasification (producer gas yield) is illustrated in Figure 8. Major important producer gas components that contribute to the gas heating value are $\mathrm{CO}, \mathrm{H}_{2}$, and light hydrocarbon gases. These gases were produced via the following:

Boudouard reaction:

$$
\mathrm{C}+\mathrm{CO}_{2} \rightarrow 2 \mathrm{CO}
$$

Carbon reaction (oxygen gasification):

$$
\mathrm{C}+0.5 \mathrm{O} \rightarrow \mathrm{CO}
$$

Shift reaction:

$$
\mathrm{CO}+\mathrm{H}_{2} \mathrm{O} \rightarrow \mathrm{CO}_{2}+\mathrm{H}_{2}
$$

Hydro gasification reaction:

$$
\mathrm{CO}+\mathrm{H}_{2} \leftrightarrow \mathrm{CH}_{4}
$$

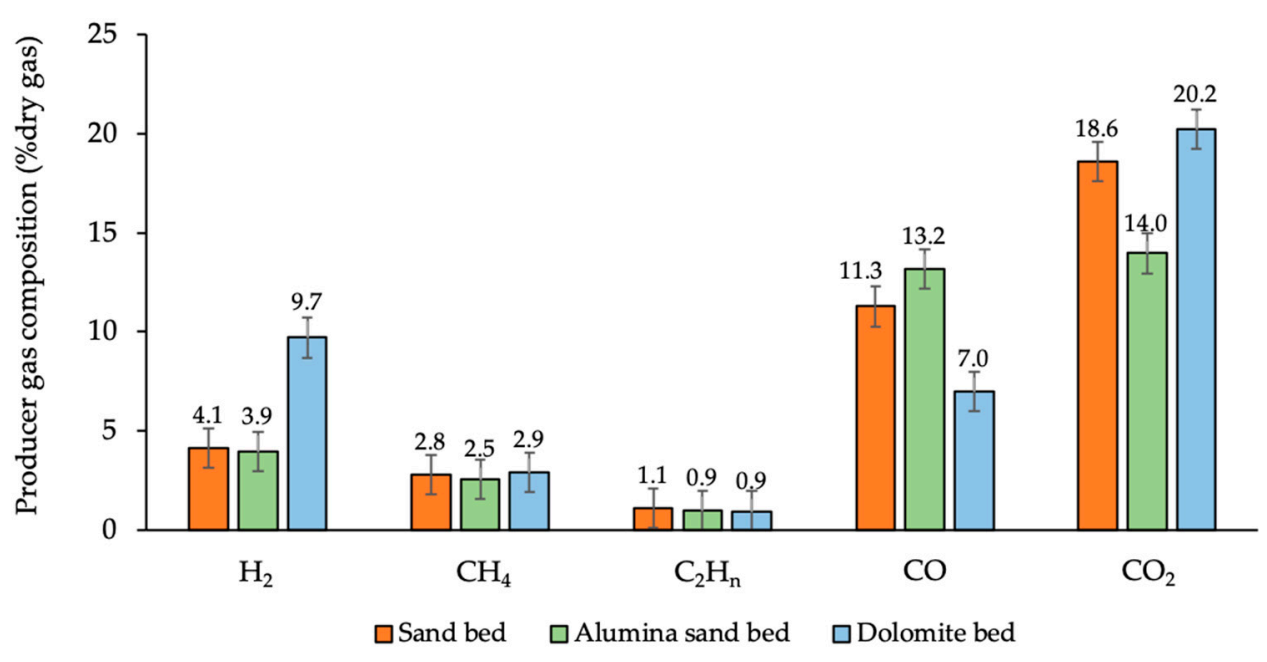

Figure 8. Composition of producer gas from EFB gasification using various bed materials. 
Normally, CO is produced via the Boudouard reaction (Equation (3)) and the carbon reaction (Equation (4)). This product continuously acts as the reactant in the shift reaction (Equation (5)) and the Hydro gasification reaction (Equation (6)), which yield $\mathrm{H}_{2}, \mathrm{CO}_{2}$, and $\mathrm{CH}_{4}$.

When using alumina sand as bed material, the $\mathrm{CO}_{2}$ yield was significantly less while $\mathrm{CO}$ was slightly higher compared to when using silica sand and dolomite as bed materials. This was because the sampling of producer gas must be carried out at lower temperature $\left(700{ }^{\circ} \mathrm{C}\right)$ before the steady state was reached, where the degree of conversion was lower. Moreover, the low fluidisation level when using alumina sand reduced the degree of reaction due to the lower surface contact between the biomass and the gasification agent (i.e., air).

When using dolomite as bed material, the gasification process involved the calcination reactions of Equations (1) and (2) in addition to the reactions of Equations (3)-(6), as previously mentioned. The $\mathrm{H}_{2}$ concentration was significantly higher compared to using silica sand and alumina sand as bed materials. The high concentration of $\mathrm{H}_{2}$ was possibly due to the reaction of Equation (5) because the presence of $\mathrm{CaO}$ from the calcination reaction in the environment could act as a catalyst for the reaction of Equation (5) [20,21].

$\mathrm{CO}_{2}$ in significantly high concentration, which was the product of the reaction of Equation (5) and the calcination reaction, continuously reacted in a catalytic dry reforming reaction, as shown in Equation (7):

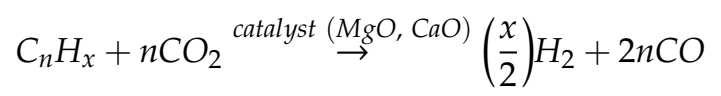

This possibly contributed to the formation of $\mathrm{K}_{2} \mathrm{CO}_{3}$ via the reaction of Equation (8):

$$
\mathrm{CO}_{2}+\mathrm{K}_{2} \mathrm{O} \rightarrow \mathrm{K}_{2} \mathrm{CO}_{3}
$$

The reforming reaction of Equation (7) resulted in a significant increase of the $\mathrm{H}_{2}$ yield and CO. Some $\mathrm{CO}$ possibly returned to the reaction of Equation (5) to reproduce $\mathrm{CO}_{2}$, which produced, as a result, the lower $\mathrm{CO}$ concentration than when using silica sand and alumina sand as bed materials.

As mentioned above, due to the agglomeration problem for the EFB experiment using silica sand and alumina sand as bed materials, the producer gas had to be collected for further analysis before the steady-state condition was reached. Only in the experiment using dolomite, the producer gas could be collected at the steady-state condition. Even though the concentrations of producer gas from various experiments were different, the heating values (HHV) of gas from different gasification experiments were in the same range, i.e., $3.8-3.9 \mathrm{MJ} / \mathrm{Nm}^{3}$.

\subsubsection{Effect of Bed Material on Cold Gasification Efficiency and Carbon Conversion Efficiency}

The cold gasification efficiency $\left(\eta_{g}\right)$ and carbon conversion efficiency $\left(\eta_{c}\right)$ of all experiments are shown in Figure 9. The experiment using dolomite yielded the best $\eta_{g}$, at $42.7 \%$. This is attributed to the higher degree of reaction obtained during the steady-state bed temperature $\left(750^{\circ} \mathrm{C}\right)$.

The producer gases from the experiment using silica sand and alumina sand were collected when bed temperature reached $700{ }^{\circ} \mathrm{C}$ to avoid poor producer gas concentration due to bed agglomeration issues for silica sand and low fluidisation level issues for alumina sand. At lower temperature and lower fluidisation level, the lower degree of reaction was expected; thus, $\eta_{\mathrm{g}}$ of the experiments with silica sand and alumina sand, i.e., $40.2 \%$ and $38.1 \%$, respectively, were slightly lower than with dolomite, i.e., $42.7 \%$. For $\eta_{c}$, the best efficiency occurred in the experiments using silica sand as the bed material: $79.3 \%$. According to issues of using dolomite and alumina sand as mentioned earlier in Sections 3.2.2 and 3.2.3, the dolomite and alumina sand experiments yielded lower efficiency, as shown in Figure 9 (74.7\% and $68.2 \%$, respectively).

Compared to rubber wood sawdust (RWS) gasification using the same bed materials, the same equipment, and the same experiment procedure from the authors' previous work [22], RWS yielded overall $\eta_{\mathrm{g}}$ and $\eta_{\mathrm{c}}$ significantly higher than EFB gasification, i.e., about $53-56 \%$ of $\eta_{\mathrm{g}}$ and $80-96 \%$ of 
$\eta_{\mathrm{c}}$. A higher degree of reaction was achieved during RWS gasification due to its more uniform size and better chemical properties including higher volatile matter and higher carbon content than EFB. However, the trend of $\eta_{\mathrm{g}}$ and $\eta_{\mathrm{c}}$ with respect to different bed materials was similar regardless of biomass type.

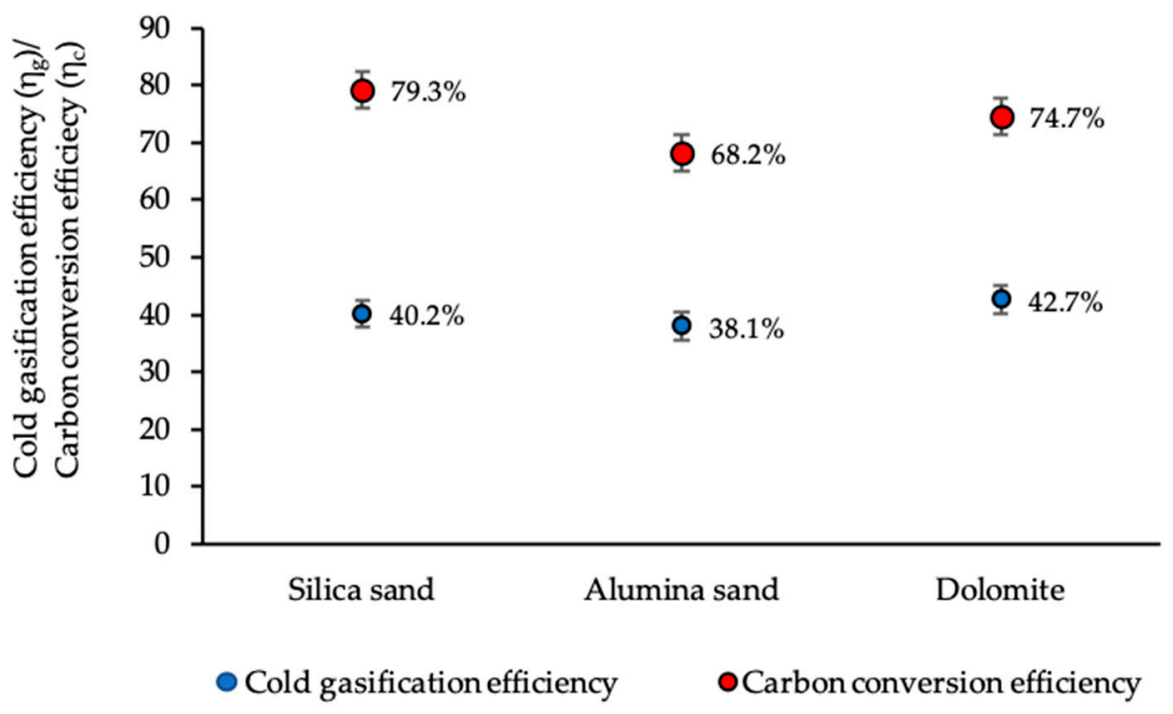

Figure 9. Cold gasification efficiency and carbon conversion efficiency of EFB gasification using various bed materials.

\section{Conclusions}

In this study, the EFB gasification experiment in a bubbling fluidised bed using silica sand, dolomite, and alumina sand at ER $=0.35$ was conducted. As expected, bed agglomeration was found in EFB gasification using silica sand as a bed material when bed temperature exceeded $750{ }^{\circ} \mathrm{C}$. The coated-induced agglomeration mechanism was found to be more dominant than melted-induced agglomeration.

Dolomite was found to be an effective alternative bed material for preventing bed agglomeration. However, using dolomite as a bed material must be carefully monitored because there would be a high level of bed particle attrition during gasification. Reduction of bed particle size could cause a high fluidisation number and could result in slug flow, which could later cause fuel blockage in the reactor. In this study, the experiment using dolomite as bed material was the only experiment that achieved a steady-state condition, i.e., no occurrence of bed agglomeration at $750{ }^{\circ} \mathrm{C}$ and yielded $\mathrm{HHV}$ and $\eta_{\mathrm{g}}$ of $3.9 \mathrm{MJ} / \mathrm{Nm}^{3}$ and $42.7 \%$, respectively.

Alumina sand can also be an alternative to reducing bed agglomeration, but in this study, it achieved a very short run time due to its relatively low fluidisation number, as a consequence of its high bulk density and the low air flow rate used. The low fluidisation number led to the low degree of reaction, which resulted in low $\eta_{\mathrm{g}}$ and $\eta_{\mathrm{c}}$.

For bed agglomeration prevention at bed temperatures below $800^{\circ} \mathrm{C}$, both dolomite and alumina sand are recommended as alternative bed materials. However, further studies for performance and cost optimization are needed. Due to the catalytic reactivity, high attrition, and loss of dolomite, its potential use as bed additive (to silica or alumina sand) is recommended for future research. With the high potential for bed agglomeration prevention, the operational range using alumina sand as bed material should also be investigated. 
Author Contributions: T.K. designed and conducted the experiments; S.F. supervised the research; T.K. wrote the manuscript; S.F. revised the manuscript.

Funding: This research received no external funding.

Conflicts of Interest: The authors declare no conflict of interest.

\section{References}

1. Zainal, Z.; Lahijani, P.; Mohammadi, M.; Mohamed, A.R. Gasification of lignocellulosic biomass in fluidized beds for renewable energy development: A review. Renew. Sustain. Energy Rev. 2019, 14, 2852-2862.

2. Matas, G.B.; Sandquist, J.; Sørum, L. Gasification of Biomass to Second Generation Biofuels: A Review. J. Energy Resour. Technol. 2012, 135. [CrossRef]

3. Basu, P. Biomass Gasification and Pyrolysis: Practical Design and Theory, Chapter 1: Introduction; Academic Press, Elsevier: Burlington, NJ, USA, 2010; pp. 1-25.

4. Chaivatamaset, P.; Sricharoon, P.; Tia, S. Bed agglomeration characteristics of palm shell and corncob combustion in fluidized bed. Appl. Therm. Eng. 2011, 31, 2916-2927. [CrossRef]

5. Visser, H.; Van, L.S.; Kiel, J. Biomass Ash-Bed Material Interactions Leading to Agglomeration in FBC. J. Energy Resour. Technol. 2008, 130. [CrossRef]

6. Visvanathan, C.; Chiemchaisri, C. Management of Agricultural Wastes and Residue in Thailand: Wastes to Energy Approach. Available online: http://faculty.ait.ac.th/visu/wp-content/uploads/sites/7/2019/01/Agriwaste2energy-Thai.pdf (accessed on 30 October 2019).

7. Department of Alternative Energy Development and Efficiency. Potential of Palm Empty Fruit Bunch. Available online: http://webkc.dede.go.th/testmax/node/2529 (accessed on 30 October 2019).

8. Lahijani, P.; Zainal, Z.A. Gasification of palm empty fruit bunch in a bubbling fluidized bed: A performance and agglomeration study. Bioresour. Technol. 2011, 102, 2068-2076. [CrossRef] [PubMed]

9. Lajijani, P.; Njafpour, G.; Zainal, Z.; Mohammadi, M. Air gasification of palm empty fruit bunch in a fluidized bed gasifier using various bed materials. In Proceedings of the World Renewable Energy Congress, Linkoping, Sweden, 8-13 May 2011; pp. 3269-3275.

10. Chaivatamaset, P.; Sricharoon, P.; Tia, S.; Bilitewski, B. The characteristics of bed agglomeration/defluidization in fluidized bed firing palm empty fruit bunch and rice straw. Appl. Therm. Eng. 2014, 70, 737-747. [CrossRef]

11. Kittivech, T.; Fukuda, S. Characteristic of Palm empty fruit bunch (EFB) gasification in a bubbling fluidized bed reactor. In Proceedings of the The 5th International Conference on Engineering, Energy and Environment, Bangkok, Thailand, 1-3 November 2017; pp. 307-312.

12. Chen, H.; Li, B.; Yang, H.; Yang, G.; Zhang, S. Experimental Investigation of Biomass Gasification in a Fluidized bed Reactor. Energy Fuels 2008, 22, 3493-3498. [CrossRef]

13. Kuprianov, V.; Ninduangdee, P.; Suheri, P. Co-firing of oil palm residues in a fuel staged fluidized-bed combustor using mixtures of alumina and silica sand as the bed material. Appl. Therm. Eng. 2018, 144, 371-382. [CrossRef]

14. Ninduangdee, P.; Kuprianov, V. Combustion of an oil palm residue with elevated potassium content in a fluidized-bed combustor using alternative bed materials for preventing bed agglomeration. Bioresour. Technol. 2015, 182, 272-281. [CrossRef] [PubMed]

15. Channiwala, S.A.; Parikh, P.P. A unified correlation for estimating HHV of solid, liquid and gaseous fuels. Fuel 2002, 81, 1051-1063. [CrossRef]

16. Waldheim, L.; Nilsson, T. Heating Value of Gases from Biomass Gasification; TPS-01/16; TPS Termiska Processer AB: Nykoping, Sweden, 2001.

17. Chaivatamaset, P.; Tia, S. The characteristics of bed agglomeration during fluidized bed combustion of eucalyptus bark. Appl. Therm. Eng. 2015, 75, 1134-1146. [CrossRef]

18. Visser, H.J.M.; Kiel, J.H.A.; Veringa, H.J. The Influence of Fuel Composition on Agglomeration Behaviour in Fluidised-Bed Combustion; ECN-C-04-054; ECN: Petten, The Netherlands, 2004.

19. Roedder, E. Silicate melt systems. Phys. Chem. Earth 1959, 3, 224-297. [CrossRef]

20. Lin, C.; Kou, J.; Wey, M.; Chang, S.; Wang, K. Inhibition and promotion: The effect of earth alkali metals and operating temperature on particle agglomeration/defluidization during incineration in fluidized bed. Powder Technol. 2009, 189, 57-63. [CrossRef] 
21. Liu, Z.; Peng, T.; Lin, C. Impact of $\mathrm{CaO}$ and $\mathrm{CaCO}_{3}$ addition on agglomeration/defluidization and heavy metal emission during waste combustion in fluidized bed. Fuel Process. Technol. 2014, 118, 171-179. [CrossRef]

22. Kittivech, T.; Fukuda, S. Effect of bed materials on gasification performance and tar reduction in a bench-scale air blown bubbling fluidized bed reactor. In Proceedings of the The 7th International Conference on Sustainable Energy and Environment (SEE 2018), Bangkok, Thailand, 28-30 November 2018.

(C) 2019 by the authors. Licensee MDPI, Basel, Switzerland. This article is an open access article distributed under the terms and conditions of the Creative Commons Attribution (CC BY) license (http://creativecommons.org/licenses/by/4.0/). 